Review began 11/11/2021 Review ended 11/17/2021 Published 11/18/2021

(c) Copyright 2021

Wassel et al. This is an open access article distributed under the terms of the Creative Commons Attribution License CC-BY 4.0., which permits unrestricted use, distribution, and reproduction in any medium, provided the original author and source are credited.

\title{
Elevated Adrenocorticotropic Hormone, Hypercortisolism, and Marked Hypernatremia
}

Elias Wassel ${ }^{1,2}$, Chukwuemeka A. Umeh ${ }^{2}$, Curren Giberson ${ }^{2}$, Simran K. Anand ${ }^{1,2}$, Anphong Nguyen ${ }^{2}$, Hayden Porter ${ }^{3}$, Prithi Choday ${ }^{2}$, Harpreet Kaur ${ }^{2}$, Ankur Kundu ${ }^{2}$, Jose Penaherrera ${ }^{2}$

1. Internal Medicine, St. George's University School of Medicine, West Indies, GRD 2. Internal Medicine, Hemet Global Medical Center, Hemet, USA 3. Radiology, Hemet Global Medical Center, Hemet, USA

Corresponding author: Chukwuemeka A. Umeh, emmyumeh@yahoo.com

\begin{abstract}
We present a case of refractory hypernatremia in a patient with elevated adrenocorticotropic hormone (ACTH) and hypercortisolism. Cortisol's effect in tissues results in various outcomes, from maintaining blood pressure to increasing serum glucose levels. In addition, cortisol, cortisone, and aldosterone activate mineralocorticoid receptors with the same affinity; therefore, the activation of mineralocorticoid receptors by elevated cortisol levels leads to increased sodium reabsorption, increased potassium secretion, and metabolic alkalosis. Hypernatremia in our patient was initially refractory to fluid replacement but was eventually corrected with intravenous fluid and desmopressin. Overall, we suggest that hypercortisolism should be considered a differential diagnosis in hypernatremia refractory to fluids replacement.
\end{abstract}

Categories: Endocrinology/Diabetes/Metabolism, Internal Medicine, Nephrology

Keywords: hyperglycemia, hypokalemia, desmopressin, case report, hypernatremia, cushing syndrome,

hypercortisolism, acth

\section{Introduction}

Cushing syndrome results from prolonged exposure to glucocorticoids and presents with specific signs and symptoms. Adrenocorticotropic hormone (ACTH) dependent Cushing syndrome is divided into Cushing disease from pituitary secretion and ectopic ACTH syndrome from an extra-pituitary secretion. Ectopic ACTH production accounts for $10 \%-20 \%$ of the cases of ACTH-dependent Cushing syndrome [1]. Common sites of paraneoplastic ACTH secretion include small cell lung carcinoma, islet cell tumor, bronchial carcinoid, and pheochromocytoma. At its physiological level, cortisol has a weak mineralocorticoid effect. However, at increased cortisol concentrations, the enhanced mineralocorticoid effect of cortisol leads to additional transcription of mineralocorticoid receptors (MRs) in the distal convoluted tubules of renal tubules, causing increased sodium reabsorption and potassium secretion [2,3]. We present a case in which hypercortisolism due to elevated ACTH caused refractory hypernatremia.

\section{Case Presentation}

A 74-year-old male with a history of two transient ischemic attacks was brought into our facility for altered mental status after being found unconscious by a relative. His social history was significant for 55 pack-years of smoking. Due to his mentation on arrival, no further history was obtained. Vital signs were normal on admission. Physical examination on admission showed non-responsiveness to sternal rub, dry mucous membranes, decreased skin turgor, and thick white plaques around the corners of his mouth. Examination of the extremities showed 1+ bilateral lower leg edema, and pulmonary examination revealed right-sided wheezes and rales.

On admission, the patient had an elevated blood glucose of $662 \mathrm{mg} / \mathrm{dL}$ (normal: $70-110 \mathrm{mg} / \mathrm{dL}$ ), an anion gap of 15 , ß-hydroxybutyrate of $1.86 \mathrm{mmol} / \mathrm{L}$ (normal: $0.02-0.27 \mathrm{mmol} / \mathrm{L}$ ), point-of-care (POC) lactate of 3.3 $\mathrm{mmol} / \mathrm{L}$ (normal: $0.5-2.0 \mathrm{mmol} / \mathrm{L}$ ), serum potassium of $3.8 \mathrm{mEq} / \mathrm{L}$, urine volume of $850 \mathrm{~mL}$, and no ketones on urinalysis. The arterial blood gas (ABG) showed a $\mathrm{pH}$ of $7.48, \mathrm{HCO}_{3}$ of 24.6 , and $\mathrm{PCO}_{2}$ of $33 \mathrm{meq} / \mathrm{L}$. The slightly elevated anion gap on admission is likely multifactorial. It could have been caused by the increase in the negative charge for albumin and enhanced production of lactate seen in metabolic alkalosis [4]. Conversely, it is also possible that scant ketones, which are produced in a hyperosmolar hyperglycemic state, as seen by mildly elevated $\beta$-hydroxybutyrate and the absence of ketones in the urine, could have contributed to the elevated anion gap [5].

Additionally, the patient had hypernatremia (sodium of $185 \mathrm{mEq} / \mathrm{L}$ corrected for hyperglycemia), acute kidney injury (blood urea nitrogen [BUN] of $49 \mathrm{mg} / \mathrm{dL}$, creatinine [Cr] of $1.55 \mathrm{mg} / \mathrm{dL}$, from a previous baseline Cr of $1.01 \mathrm{mg} / \mathrm{dL}$ ), and hemoconcentration (hemoglobin [Hb] $17.1 \mathrm{~g} / \mathrm{dL}$, hematocrit [Hct] 51.6\%). Chest X-ray indicated a potential right lower lung zone infiltrate. Computed tomography (CT) of the chest indicated right lower lobe mass or consolidation, with multiple mediastinal and hilar masses as well as enlarged left axillary nodes compatible with lymphadenopathy, suggestive of malignancy and metastatic disease (Figures 


\section{Cureus}

1, 2). CT of the abdomen showed heterogeneous liver attenuation but could not differentiate between nonocclusive disease and metastatic disease. Adrenal nodules and kidney nodular densities were also present (Figure 3). CT of the brain showed a suprasellar mass measuring $1.2 \times 1.1 \times 0.9 \mathrm{~cm}$ (Figure 4). The patient was started on half normal saline and insulin, and the acute kidney injury significantly improved on day 3; however, no significant improvement in sodium level was noticed after correction for elevated glucose levels (Figure 5 and Table 1 ).

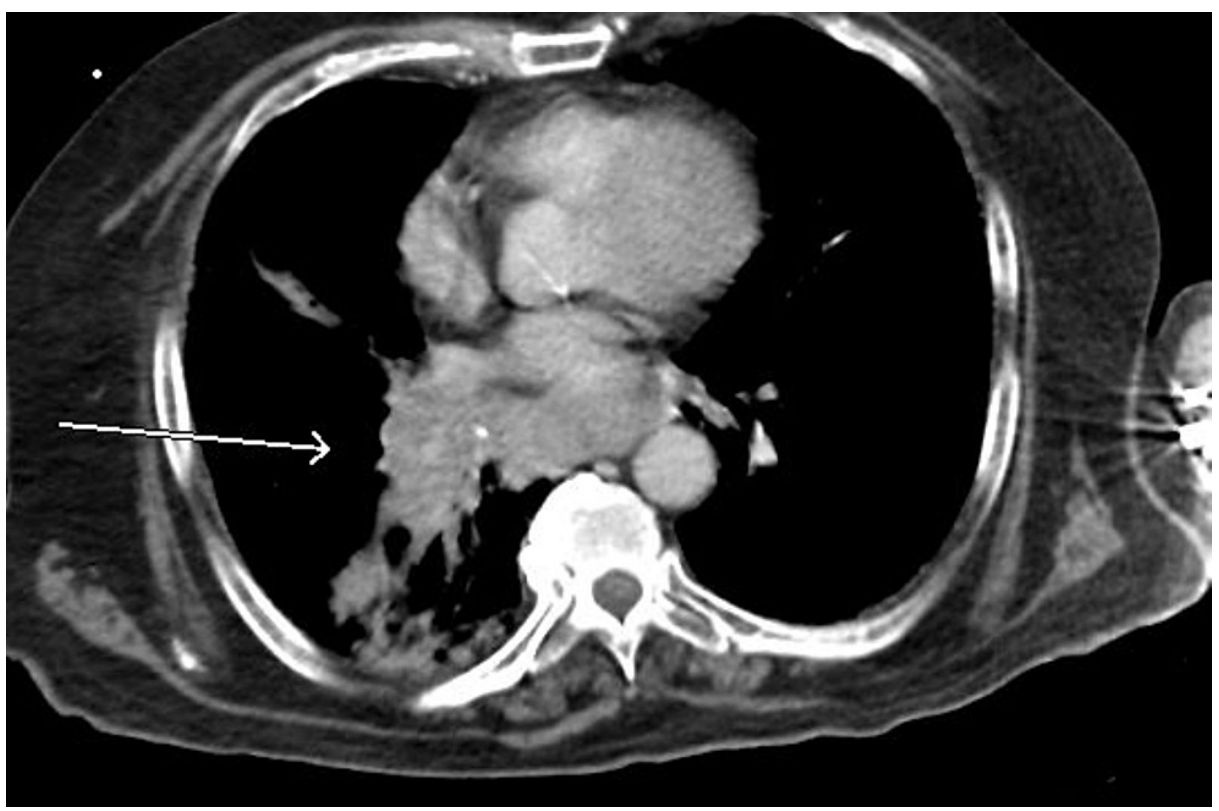

FIGURE 1: CT of the chest (axial view) showing a mediastinal mass

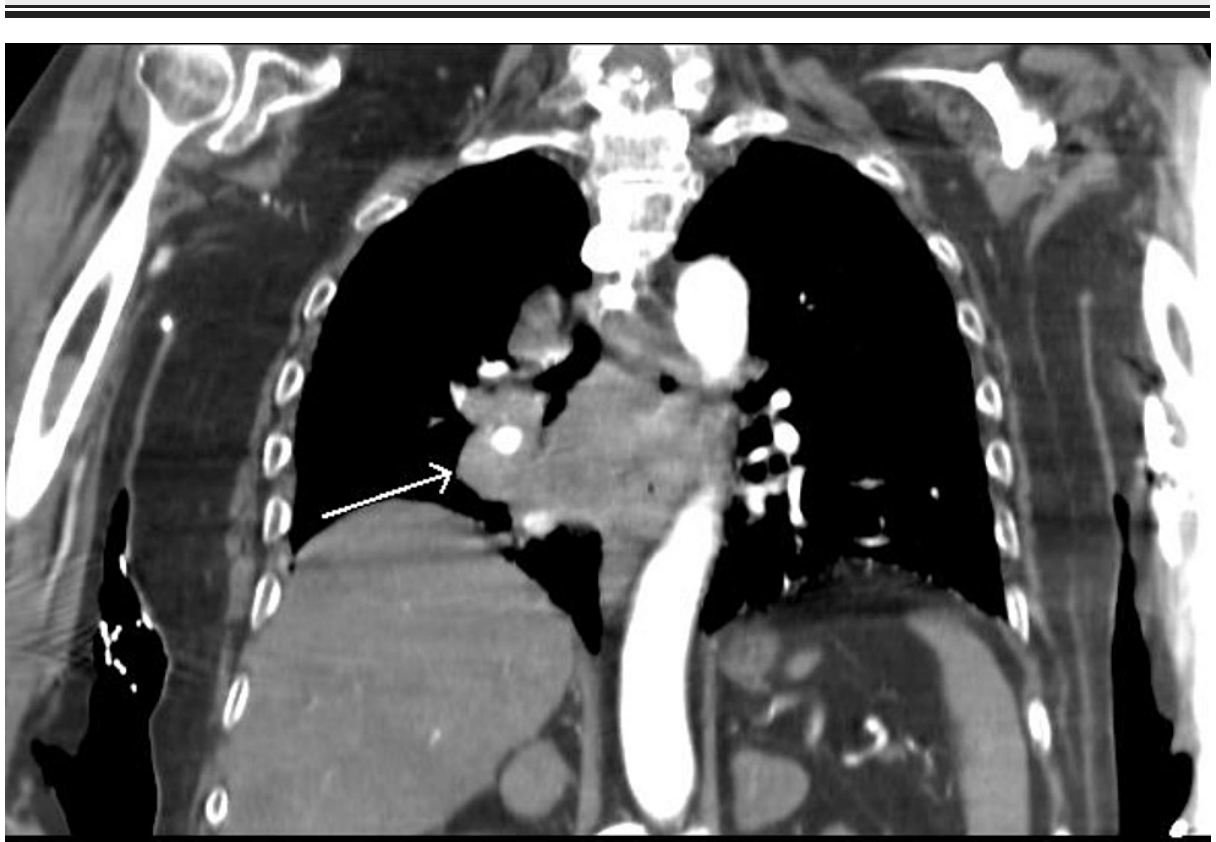

FIGURE 2: CT of the chest (coronal view) showing a mediastinal mass 


\section{Cureus}

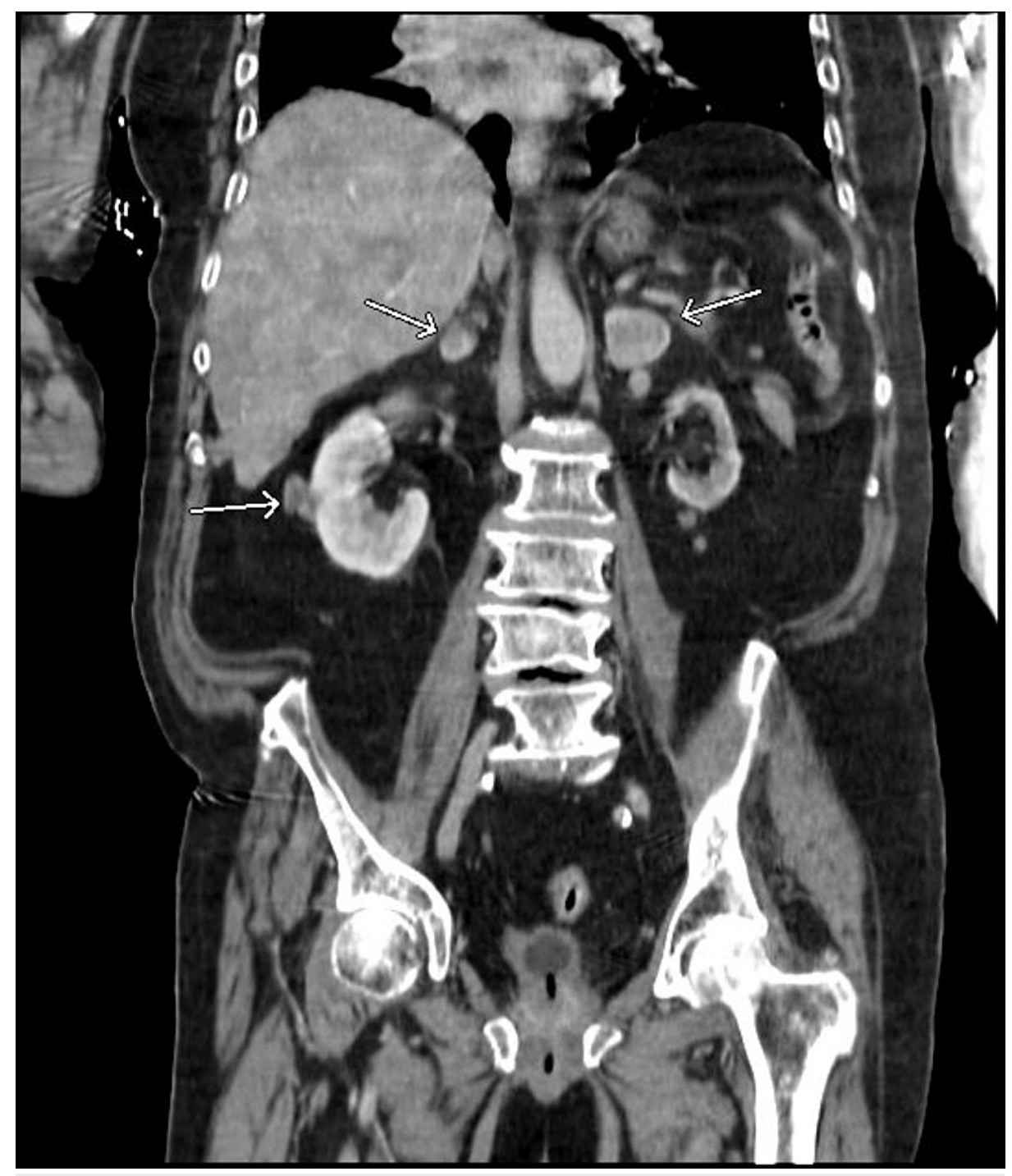

FIGURE 3: CT of the abdomen (coronal view) showing adrenal nodules and kidney nodular densities 


\section{Cureus}

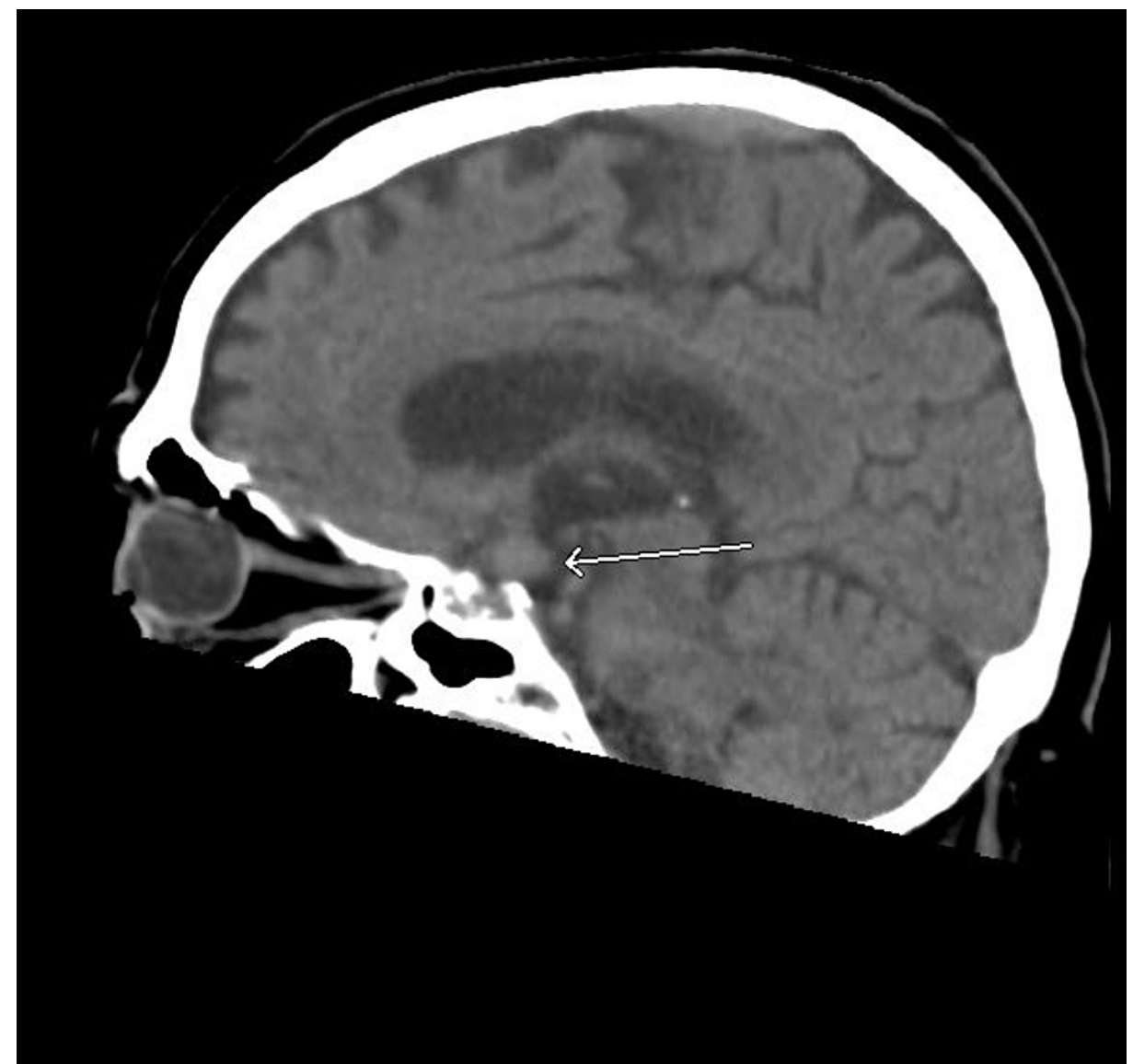

FIGURE 4: CT of the brain (sagittal view) showing a suprasellar mass

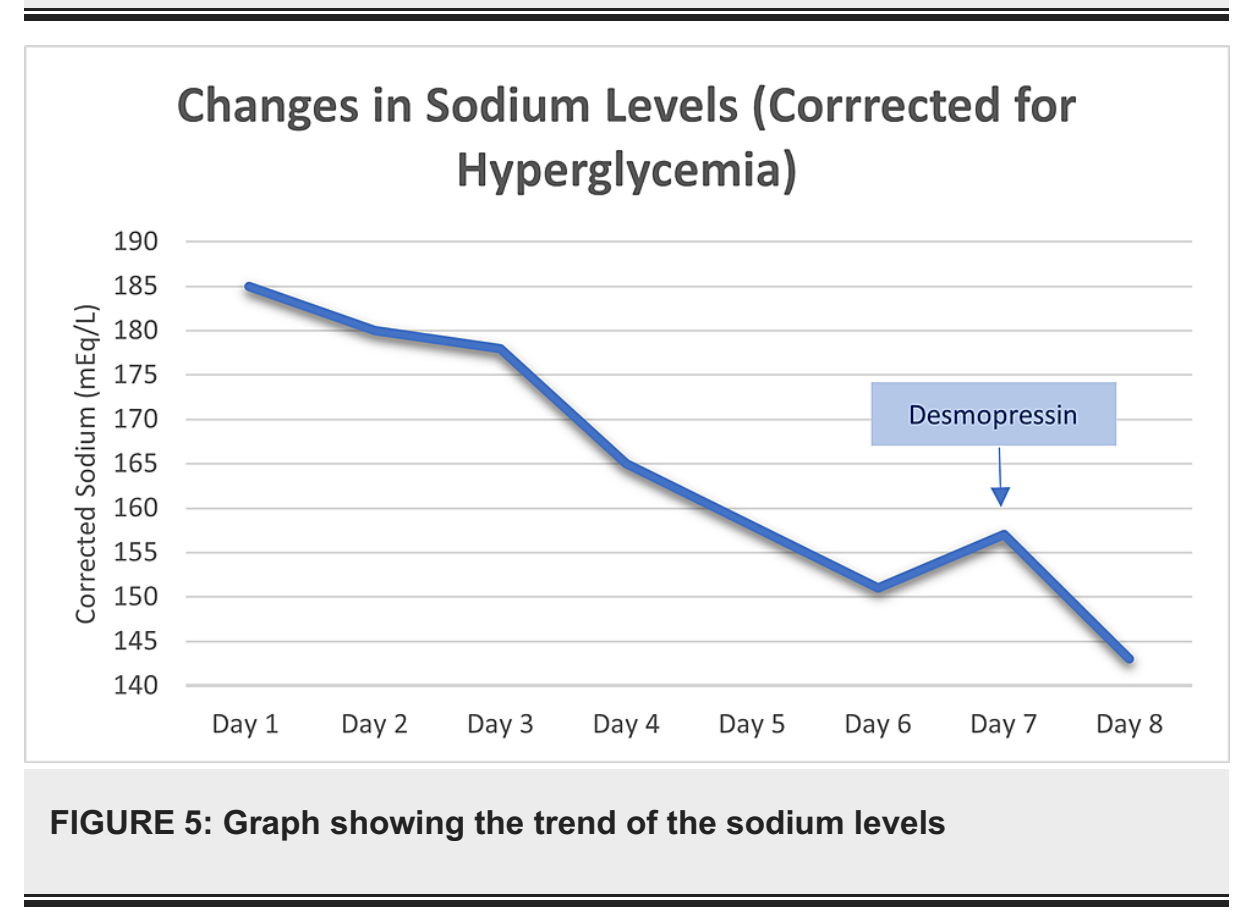




\section{Cureus}

\begin{tabular}{|l|l|l|l|l|l|l|l|l|}
\hline & Day $\mathbf{1}$ & Day $\mathbf{2}$ & Day 3 & Day 4 & Day 5 & Day $\mathbf{6}$ & Day $\mathbf{7}$ & Day 8 \\
\hline Sodium (mEq/L) & 172 & 177 & 178 & 162 & 154 & 149 & 153 & 138 \\
Corrected sodium (mEq/L) & 185 & 180 & 178 & 165 & 158 & 151 & 157 & 143 \\
Glucose (mg/dL) & 662 & 209 & 95 & 222 & 266 & 174 & 284 & 308 \\
\hline
\end{tabular}

\section{TABLE 1: Glucose and sodium level changes}

Additional investigations for the refractory hypernatremia showed a urine osmolarity of 699 (normal: 501,400), serum osmolarity of 360 (normal: 280-301), urine sodium of $10 \mathrm{mEq} / \mathrm{L}$ (normal: $20 \mathrm{mEq} / \mathrm{L}$ ), serum AM cortisol of $61.3 \mathrm{ug} / \mathrm{dL}$ (normal AM: 6.2-19.4 ug/dL), 1-mg dexamethasone suppression test cortisol of 6.06 $\mathrm{ug} / \mathrm{dL}$ (normal: $<1.8 \mathrm{ug} / \mathrm{dL}$ ) and ACTH of $228 \mathrm{pg} / \mathrm{mL}$ (normal: $7.2-63.3 \mathrm{pg} / \mathrm{mL}$ ) (Table 2). MRI of the brain revealed a $1.1 \times 1.2 \times 1.1 \mathrm{~cm}$ enhancing lesion of the optic chiasm without evidence of mass effect (Figure 6) and small lymph nodes in deep portions of the bilateral parotid glands that were potential metastasis. Throughout the admission, the patient's arterial blood gas (ABG) showed a primary respiratory alkalosis with secondary metabolic alkalosis ( $\mathrm{pH}$ of $7.48, \mathrm{HCO}_{3}$ of $24.6, \mathrm{PCO}_{2}$ of $33 \mathrm{meq} / \mathrm{L}$ ), which was persistent until discharge ( $\mathrm{pH}$ of $7.48, \mathrm{HCO}_{3}$ of $27.6 \mathrm{meq} / \mathrm{L}, \mathrm{PCO}_{2}$ of $37 \mathrm{mmHg}$ ). Additional endocrine investigations demonstrated an follicle-stimulating hormone (FSH) of $0.3 \mathrm{miU} / \mathrm{L}$ (normal: 1.5-12.4 miU/L), luteinizing hormone (LH) $<0.3 \mathrm{miU} / \mathrm{L}$ (normal: 1.7-8.6 miU/L), testosterone of $27 \mathrm{ng} / \mathrm{dL}$ (normal: $264-916 \mathrm{ng} / \mathrm{dL}$ ), thyroid-stimulating hormone (TSH) of $0.01 \mathrm{u} / \mathrm{iU} / \mathrm{L}$ (normal: $0.34-5.60 \mathrm{u} / \mathrm{iU} / \mathrm{L}$ ), and prolactin of $9.7 \mathrm{ng} / \mathrm{mL}$ (normal: 4.0-15.2 ng/mL). The plan was to obtain a lung biopsy to determine whether the mass was cancerous or not and to conduct a high dexamethasone suppression test for ectopic ACTH production. However, the patient declined further workup or treatment, opting for hospice instead. 


\section{Cureus}

\begin{tabular}{|c|c|c|}
\hline & Patient & Normal \\
\hline Sodium (mEq/L) & 172 & 135-145 \\
\hline Potassium (mEq/L) & 3.8 & $3.5-5.1$ \\
\hline Chloride (meq/L) & 123 & 98-107 \\
\hline $\mathrm{CO}_{2}(\mathrm{mEq} / \mathrm{L})$ & 26 & $21-31$ \\
\hline BUN (mg/dL) & 49 & $7-25$ \\
\hline Creatinine $(\mathrm{mg} / \mathrm{dL})$ & 1.55 & $0.7-1.3$ \\
\hline WBC $\left(10^{3} / \mathrm{mL}\right)$ & 9.1 & 3.6-11.2 \\
\hline Hemoglobin (g/dL) & 17.1 & $12.5-16.3$ \\
\hline Hematocrit (\%) & 51.6 & $36.7-47.1$ \\
\hline Blood glucose (mg/dL) & 662 & $70-110$ \\
\hline ß-hydroxybutyrate (mmol/L) & 1.86 & $0.02-0.27$ \\
\hline Urine osmolarity & 699 & $50-1400$ \\
\hline Serum osmolarity & 360 & $280-301$ \\
\hline Urine sodium (mEq/L) & 10 & 20 \\
\hline Serum AM cortisol (ug/dL) & 61.3 & $6.2-19.4$ \\
\hline ACTH (pg/mL) & 228 & $7.2-63.3$ \\
\hline FSH (miU/L) & 0.3 & $1.5-12.4$ \\
\hline LH (miU/L) & $<0.3$ & $1.7-8.6$ \\
\hline Testosterone (ng/dL) & 27 & $264-916$ \\
\hline TSH (u/iU/L) & 0.01 & $0.34-5.60$ \\
\hline Prolactin (ng/mL) & 9.7 & $4.0-15.2$ \\
\hline
\end{tabular}

\section{TABLE 2: Laboratory values on admission}

$\mathrm{CO}_{2}$, carbon dioxide; BUN, blood urea nitrogen; WBC, white blood cells; ACTH, adrenocorticotropic hormone; FSH, follicle-stimulating hormone; LH, luteinizing hormone; TSH, thyroid-stimulating hormone 


\section{Cureus}

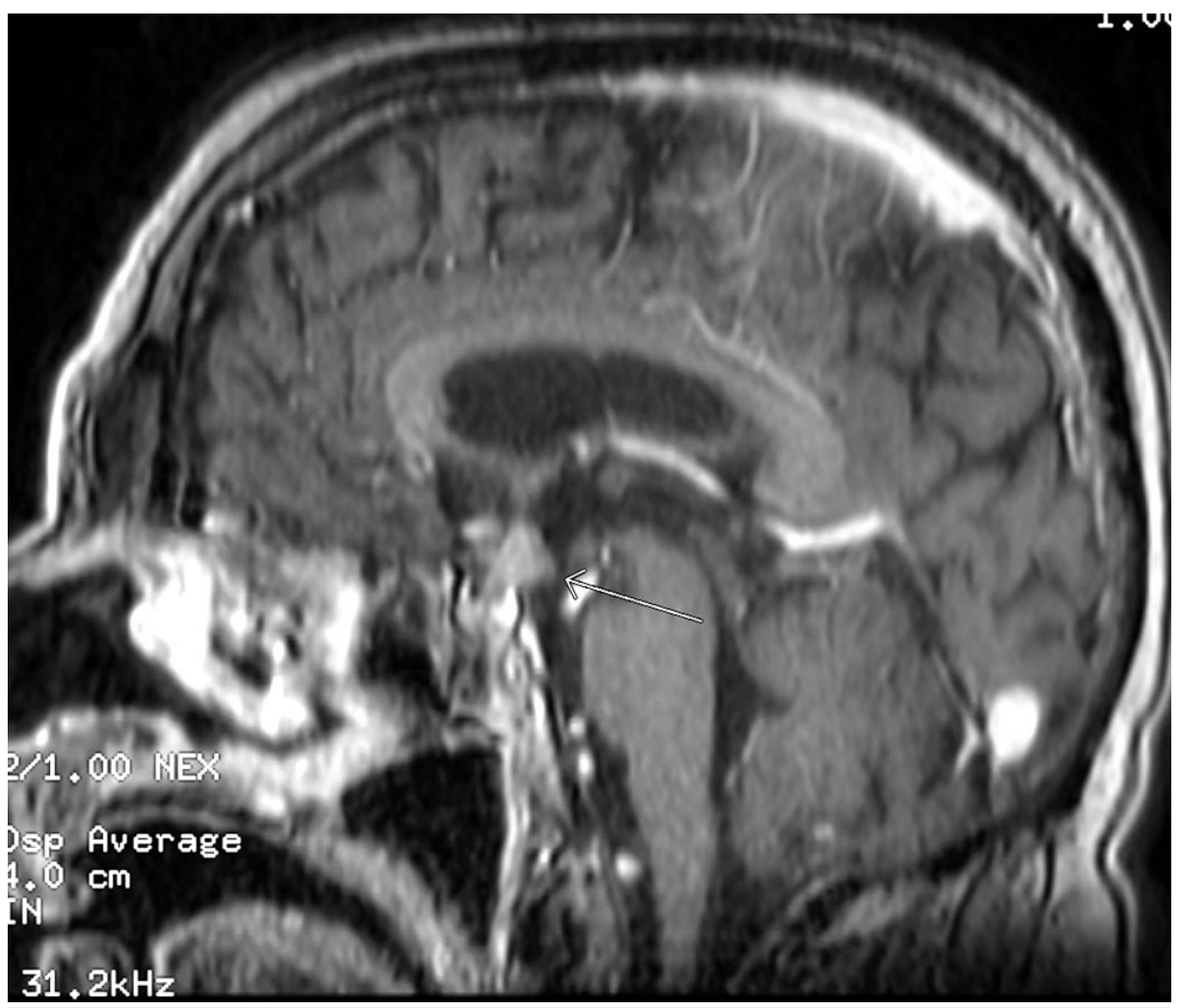

FIGURE 6: MRI of the brain (sagittal view) showing a contrast-enhancing lesion of the optic chiasm

Despite initial fluid resuscitation with half normal saline followed by dextrose water, the hypernatremia did not correct. The hypernatremia later resolved after the patient was started on desmopressin on day 7 of admission. The patient was sent home on hospice and was advised to increase his water intake.

\section{Discussion}

Cortisol induces gluconeogenesis and glycogenolysis and decreases insulin secretion, leading to increased glucose levels, as seen in our patient. Furthermore, elevated cortisol levels activate MRs in the renal tubules, which enhance the transcription of epithelial sodium channels (eNAC) and $\mathrm{Na}+/ \mathrm{K}+$ ATPase channels [6]. The increased sodium and potassium channels in the luminal membrane and increased activity of the $\mathrm{Na}+/ \mathrm{K}+$ ATPase channel in the basolateral membrane result in increased sodium reabsorption and potassium excretion [6,7]. The sustained activation of MRs leads to increased reabsorption of $\mathrm{HCO}_{3}$, leading to metabolic alkalosis [8]. These changes result in hypernatremia, hypokalemia, and metabolic alkalosis, as was seen in our patient. Further workup for Cushing disease was not conducted due to the patient's request for hospice. However, the absence of Cushing stigmata, such as truncal/central obesity, round face, supraclavicular fat, and a buffalo hump, made Cushing disease unlikely. Consequentially, this increased our suspicion for ectopic ACTH production as a paraneoplastic syndrome. Treatment for ectopic ACTH production includes tumor excision when the source is known [9]. However, when the source of ectopic ACTH production is unknown, pharmacological treatment to suppress cortisol suppression is used, such as metyrapone or ketoconazole [9].

Our patient presented with hyperglycemia, hypernatremia, and metabolic alkalosis secondary to hypercortisolism. He received intravenous fluids without improvement in his hypernatremia. Therefore, after seven days, desmopressin was started to correct the hypernatremia. Desmopressin (1-deamino-8-Darginine vasopressin; DDAVP) therapy decreased sodium levels by stimulating antidiuretic hormone (ADH) receptors in renal collecting ducts, leading to increased water absorption. In addition, DDAVP leads to increased water absorption through $\mathrm{V} 2$ receptors in the renal collecting duct, which leads to a decrease in serum sodium level [10]. Alternative treatments include eNAC channel blockers such as amiloride [11]; however, due to the need to regularly monitor potassium levels, this was not a choice for our patient who was discharged home on hospice.

\section{Conclusions}

MRs have the same affinity for aldosterone, cortisol, and corticosterone. Thus, in hypercortisolism, MRs 
enhance sodium reabsorption in exchange for hydrogen and potassium ions in the renal tubules, resulting in hypernatremia, hypokalemia, and metabolic alkalosis. Therefore, we suggest that hypercortisolism should always be considered in cases of refractory hypernatremia, especially if a patient is hyperglycemic or hypokalemic. In summary, we presented a case of excess cortisol-induced hypernatremia, which was refractory to initial fluid therapy.

\section{Additional Information \\ Disclosures}

Human subjects: Consent was obtained or waived by all participants in this study. Conflicts of interest: In compliance with the ICMJE uniform disclosure form, all authors declare the following: Payment/services info: All authors have declared that no financial support was received from any organization for the submitted work. Financial relationships: All authors have declared that they have no financial relationships at present or within the previous three years with any organizations that might have an interest in the submitted work. Other relationships: All authors have declared that there are no other relationships or activities that could appear to have influenced the submitted work.

\section{References}

1. Anaforoğlu I, Ersoy K, Aşık M, Karyağar S, Algün E: Diagnosis of an ectopic adrenocorticotropic hormonesecreting bronchial carcinoid by somatostatin receptor scintigraphy. Clinics (Sao Paulo). 2012, 67:973-5. 10.6061/clinics/2012(08)21

2. Gomez-Sanchez E, Gomez-Sanchez CE: The multifaceted mineralocorticoid receptor. Compr Physiol. 2014, 4:965-94. 10.1002/cphy.c130044

3. Fan L, Zhuang Y, Wang Y, et al.: Association of hypokalemia with cortisol and ACTH levels in Cushing's disease. Ann N Y Acad Sci. 2020, 1463:60-6. 10.1111/nyas.14205

4. Madias NE, Ayus JC, Adrogué HJ: Increased anion gap in metabolic alkalosis: the role of plasma-protein equivalency. N Engl J Med. 1979, 300:1421-3. 10.1056/NEJM197906213002507

5. Adeyinka A, Kondamudi NP: Hyperosmolar hyperglycemic nonketotic coma. StatPearls [Internet]. StatPearls Publishing, Treasure Island, FL; 2021.

6. Furman BL: Eplerenone. Enna SJ, Bylund DB (ed): Elsevier, Amsterdam; 2008. 10.1016/B978-0-12-8012383.98013-9

7. Joëls M, Sarabdjitsingh RA, den Boon FS, Karst H: Rapid and slow effects of corticosteroid hormones on hippocampal activity. Stress: Neuroendocrinology and Neurobiology: Handbook of Stress Series. 2016, 2:327-41. 10.1016/B978-0-12-802175-0.00033-4

8. Ayuzawa N, Nishimoto M, Ueda K, et al.: Two mineralocorticoid receptor-mediated mechanisms of pendrin activation in distal nephrons. J Am Soc Nephrol. 2020, 31:748-64. 10.1681/ASN.2019080804

9. Sakihara S, Kageyama K, Yamagata S, Terui K, Daimon M, Suda T: A case of ectopic ACTH syndrome treated with intermittent administration of dopamine agonists. Endocrinol Diabetes Metab Case Rep. 2014, 2014:140001. 10.1530/EDM-14-0001

10. Hanouna G, Haymann JP, Baud L, Letavernier E: Vasopressin regulates renal calcium excretion in humans . Physiol Rep. 2015, 3:10.14814/phy2.12562

11. Rankin GO: Amiloride. xPharm: The Comprehensive Pharmacology Reference. Enna SJ, Bylund DB (ed): Elsevier, Amsterdam; 2008. 1-6. 10.1016/B978-008055232-3.63856-5 